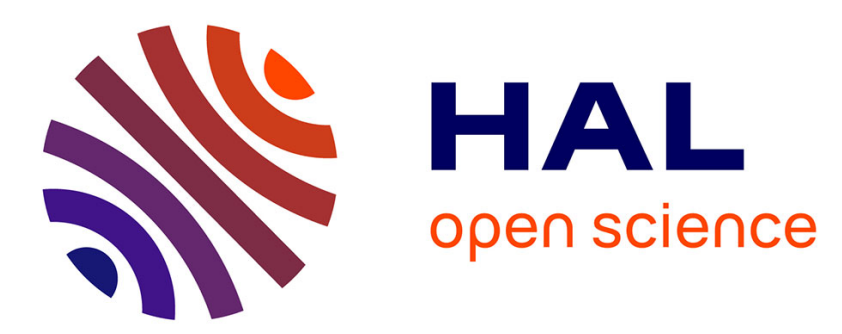

\title{
Oxygen Reduction Reaction on Metal and Nitrogen-Doped Carbon Electrocatalysts in the Presence of Sodium Borohydride
}

Ricardo Sgarbi, Edson Ticianelli, Frédéric Maillard, Frederic Jaouen, Marian Chatenet

\section{To cite this version:}

Ricardo Sgarbi, Edson Ticianelli, Frédéric Maillard, Frederic Jaouen, Marian Chatenet. Oxygen Reduction Reaction on Metal and Nitrogen-Doped Carbon Electrocatalysts in the Presence of Sodium Borohydride. Electrocatalysis, 2020, 11 (4), pp.365-373. 10.1007/s12678-020-00602-1 . hal-02931375

\section{HAL Id: hal-02931375 \\ https://hal.science/hal-02931375}

Submitted on 8 Sep 2020

HAL is a multi-disciplinary open access archive for the deposit and dissemination of scientific research documents, whether they are published or not. The documents may come from teaching and research institutions in France or abroad, or from public or private research centers.
L'archive ouverte pluridisciplinaire HAL, est destinée au dépôt et à la diffusion de documents scientifiques de niveau recherche, publiés ou non, émanant des établissements d'enseignement et de recherche français ou étrangers, des laboratoires publics ou privés. 


\title{
Oxygen Reduction Reaction on Metal and Nitrogen-Doped Carbon Electrocatalysts in the Presence of Sodium Borohydride
}

Ricardo Sgarbi ${ }^{1,2}$, Edson A. Ticianelli ${ }^{2}$, Frédéric Maillard ${ }^{1}$, Frédéric Jaouen ${ }^{3}$, and Marian Chatenet $^{1 *}$

\footnotetext{
${ }^{1}$ Univ. Grenoble Alpes, Univ. Savoie Mont Blanc, CNRS, Grenoble INP (Institute of Engineering Univ. Grenoble Alpes), LEPMI, 38000 Grenoble, France

${ }^{2}$ Instituto de Química de São Carlos, Universidade de São Paulo, Avenida Trabalhador Sãocarlense, 400 Parque Arnold Schmidt, CP 780 13560-970 São Carlos, SP, Brazil

${ }^{3}$ Institut Charles Gerhardt Montpellier, UMR 5253 CNRS/UM/ENSCM, Université de Montpellier, place Eugène Bataillon, 34095 Montpellier Cedex 5, France
}

*Corresponding authors

Email address: Marian.Chatenet@grenoble-inp.fr (Marian Chatenet);

Frederic.Maillard@lepmi.grenoble-inp.fr (Frédéric Maillard)

ORCID

Ricardo Sgarbi: 0000-0002-1337-9596

Edson A. Ticianelli: 0000-0003-3432-2799

Frédéric Maillard: 0000-0002-6470-8900

Frédéric Jaouen: 0000-0001-9836-3261

Marian Chatenet: 0000-0002-9673-4775

\begin{abstract}
Metal and nitrogen-doped carbons electrocatalysts ( $\mathrm{M}-\mathrm{N}-\mathrm{C}$, where $\mathrm{M}$ is $\mathrm{Fe}$ or $\mathrm{Co})$ are investigated for the oxygen reduction reaction (ORR) in alkaline conditions in the presence of borohydride ions $\left(\mathrm{BH}_{4}^{-}\right)$. The electrochemical properties of the Fe-N-C and Co-N-C catalysts were investigated by cyclic voltammetry and rotating disk electrode
\end{abstract}


techniques: their ORR electrocatalytic activity was bridged to their physico-chemical properties, mainly type of metallic center (Fe vs. Co), structure (atomic dispersion vs. nanoparticles) and BET surface area. It is found that Fe-N-C catalysts have the best performances for the ORR electrocatalysis, even in presence of $\mathrm{BH}_{4}^{-}$anions. The atomically-dispersed $\mathrm{Fe}$ - and Co-containing electrocatalysts reach better $\mathrm{BH}_{4}$--tolerance than their counterparts baring nanoparticles. For the atomically dispersed Fe-N-C electrocatalysts, the lowest BET surface area material generates a slight advantage of ORR mass activity and a poor (and desired) activity for borohydride oxidation reaction (BOR).

Keywords: metal-nitrogen doped carbons (M-N-C), catalyst, Fe-N-C, Co-N-C, oxygen reduction reaction, direct borohydride fuel cells.

\section{Introduction}

Small mobile electric devices (e.g. either portable electronics or drones) require power systems of high energy density. They are usually powered by batteries, but these "closed systems" are inherently limited by their insufficient specific energy $(e . g .<250$ $\mathrm{Wh} \mathrm{kg}^{-1}$ for the most energetic Li-ion systems [1]). Fuel cells, being open systems, are intrinsically denser in energy, and could therefore advantageously be used in such devices. The present standard is the proton exchange membrane fuel cell (PEMFC), which is, in its state-of-the-art, fed by pure hydrogen [2]. While transporting, compressing and storing gaseous hydrogen may prove relevant for large quantities of energy stored, this solution is not always efficient, safe, economically-viable and therefore relevant in applications where smaller amount of energy is stored, i.e. the particular case for small mobile electric devices. In that situation, the direct oxidation of a liquid fuel may be more 
desirable, and direct methanol fuel cells (DMFC) have historically been studied as the pioneer direct liquid fuel cell (DLFC) [3]. However, electrooxidizing methanol is a complex and slow process (not speaking from the toxicity of the fuel), which requires extensive amounts of platinum-group-metal (PGM) electrocatalyst, and this is a clear hindrance to the development of DMFCs, should they be acidic or alkaline $[2,4]$. While other hydrocarbon fuels have been tried as well, none proved capable to provide both sufficient energy and power density (even in alkaline environments, known to facilitate the reactions and hence to render them faster [5]), a clear drawback for the powering of small electronic devices. This triggered intense research to find more suitable liquid fuels for portable/small mobility application; from these works, sodium borohydride soon appeared as a promising candidate, owing to the properties of its fuel $[6,7]$ and of its relevance for portable fuel cell system design [8-11].

Of course, the direct oxidation of the borohydride anion $\left(\mathrm{BH}_{4}^{-}\right)$in a direct borohydride fuel cell (DBFC) is not an easy process, and many works addressed the issue, so as to isolate the reaction mechanisms [12-18], the proper electrocatalysts for the anode [19] and the ideal fuel composition, electrode structure, operating parameters of the anode, etc. [20-23]. While one shall not neglect research actions to improve our understanding of the borohydride oxidation reaction (BOR) and hence to find better materials to achieve it efficiently, one must also not neglect the membrane/separator that should separate the anode and cathode compartment. To date, cation-exchange membranes are more mature than their anion-exchange counterparts, and bipolar membranes are at an early stage of development. All types of ion-exchange membranes can be used in a DBFC (see for example [24,25]), and, whatever the nature of the membrane/separator, there are drawbacks to their utilization. For a cation-exchange membrane, during DBFC operation, the $\mathrm{Na}^{+}$cation shall migrate to the cathode, where it 
will combine with the $\mathrm{OH}^{-}$species formed in the alkaline oxygen reduction reaction (ORR), thereby displacing the $\mathrm{NaOH}$ from the anolyte to the cathode side. This naturally has a clear detrimental effect on the operation of the cathode, as recently put forth by Ould-Amara et al. [26], owing to deleterious crystallization of $\mathrm{NaOH}$ in the cathode pores, leading to unavoidable mass-transport hindrances. Should an anion-exchange membrane be used (this is probably the desired situation, as the anolyte of a DBFC is necessarily alkaline $[27,28]$ ), there will be non-negligible crossover of borohydride anions from the fuel anolyte to the cathode compartment. In that latter case, of course, the cathode catalyst must be tolerant to $\mathrm{BH}_{4}{ }^{-}$, otherwise its apparent ORR activity will be significantly affected, because either the net current will be the sum of the cathodic (desired) ORR and anodic (undesired) BOR contributions, or because borohydride species will adversely adsorb or react with the catalyst material and deactivate or chemically modify it. This shows that the cathode of a DBFC should also be tightly optimized, and in particular that $\mathrm{BH}_{4}^{-}$-tolerant $\mathrm{ORR}$ catalysts must be selected for the application [10].

The literature regarding fuel-tolerant electrocatalysts for alkaline fuel cells is abundant, but mainly deals with tolerance to hydrocarbon molecules (methanol, ethanol, etc.) [29-33]. The case of borohydride, a very strong reducer, has been less under focus, even if some (rare) studies have explored the issue. Metal-oxides (e.g. perovskites, $\mathrm{LaNi}_{0.8} \mathrm{Co}_{0.2} \mathrm{O}_{3}$ [34] and carbon-supported nanometric manganese oxides, $\mathrm{MnO}_{\mathrm{x}} / \mathrm{C}$ ) $[35,36]$ have demonstrated some interesting properties for potential use in DBFC cathodes, but one could question the durability of such inherently-oxidized materials in strongly-reducing environments; as a matter of fact, long-term stability data was never reported in such studies, except for $\mathrm{MnO}_{\mathrm{x}} / \mathrm{C}$ (but not in presence of $\mathrm{BH}_{4}^{-}$species) [37]. 
Cheng and Scott [38] explored PGM-free electrocatalysts (iron tetramethoxyphenyl porphyrin (FeTMPP), silver and nickel), regarding their ORR performances in direct borohydride fuel cell cathodes. FeTMPP cathodes outperformed silver and nickel ones, which led the authors to the conclusion that FeTMPP was somewhat $\mathrm{BH}_{4}{ }^{-}$-tolerant, unlike $\mathrm{Ag}$ and $\mathrm{Ni}$ (the latter is no surprise, as both $\mathrm{Ag}[39,40]$ and especially Ni [41-43] are active catalysts for the BOR). More recently Fe-aminoantipyrine (Fe-AAPyr) was successfully developed as a $\mathrm{BH}_{4}{ }^{-}$-tolerant ORR catalyst for a mixed-reactant DBFC [44]. These last two materials fall into the category of metal-nitrogen-carbon (M-N-C) catalysts, which are now under tremendous focus to replace Pt-based ones for PEMFC applications (see e.g. [45-47]). Because these classes of material are commonly-admitted to be tolerant to fuel species, and some of them have indeed shown tolerance to borohydride $[38,44]$, the present contribution explores two families of $\mathrm{M}-\mathrm{N}-\mathrm{C}$ compounds, based on cobalt and iron metal centers. It notably aims to unveil whether any such catalysts are tolerant to $\mathrm{BH}_{4}^{-}$, or if they must have particular features to be tolerant; herein are compared the nature of the metal (iron, $\mathrm{Fe}$, and cobalt, $\mathrm{Co}$ ), the structure of the resulting electrocatalyst (atomically-dispersed vs. nanoparticles) and its mode of synthesis (flash vs. ramp pyrolysis in argon atmosphere).

\section{Materials and methods}

\subsection{Catalysts syntheses}

The electrocatalysts used in this study were synthesized using the method described by Ranjbar-Sahraie et al. [48]. In brief, a zinc(II) zeolitic imidazolate framework (ZIF-8, purchased from BASF, Basolite Z1200), Fe or Co acetate precursor and 1,10-phenanthroline were mixed via dry planetary ball milling. The masses of the precursors were $200 \mathrm{mg}$ phenanthroline, $800 \mathrm{mg}$ ZIF-8 and either 0.5 wt. \% or 5.0 wt. \% 
of metal ( $\mathrm{Fe}$ or $\mathrm{Co}$ ) compared to the overall mass of the three precursors. The dry mixed metal, carbon and nitrogen precursors were then pyrolyzed either in flash- (i.e. the powder was introduced at $1050^{\circ} \mathrm{C}$ in the oven) or ramp-(the powder was heated from room temperature to $1050^{\circ} \mathrm{C}$ at $5^{\circ} \mathrm{C} \mathrm{min}-1$ ) mode, and a temperature of $1050^{\circ} \mathrm{C}$ was maintained for $1 \mathrm{~h}$. Then, the quartz tube and boat were opened and quenched to room temperature while still flowing Ar. As Ar was used, the weight loss during the pyrolysis was $c a$. 6575 wt. \% and it was independent on the pyrolysis mode.

\subsection{Physicochemical characterizations}

All physicochemical characterizations have been previously published, then, here only a brief overview is presented (for detailed experimental specifications, the readers could refer to References [48-52]). TEM measurements were performed on a JEM$2100 \mathrm{HCKM}$ (JEOL) microscope operating at $120 \mathrm{keV}$ for the atomically-dispersed metal atoms electrocatalysts [48,50] and a JEOL 2010 TEM microscope operating at $200 \mathrm{kV}$ for the metal nanoparticulated electrocatalysts [51]. To obtain ${ }^{57} \mathrm{Fe}$ Mössbauer spectra and confirm the absence of zerovalent iron crystalline phases in atomically-dispersed metal atom electrocatalysts, Fe-containing samples were measured with ${ }^{57} \mathrm{Co}-\mathrm{Rh}$ source and analyzed doublet and sextet spectral components ([51] for $\mathrm{Fe}_{5.0} \mathrm{RP}$ and $\mathrm{Fe}_{0.5} \mathrm{RP}$;[52] for $\mathrm{Fe}_{0.5} \mathrm{FP}$ ). The carbon nanocrystallites were characterized by Raman Spectroscopy using an argon LASER (514 nm) and X-ray Diffraction by an X'Pert PRO MPD PANalytical diffractometer operated at $45 \mathrm{kV}$ [51]. Surface area and pore volume were estimated by the Brunauer-Emmett-Teller (BET) method using a Micromeritics ASAP 2020 equipment with $\mathrm{N}_{2}$ sorption at liquid nitrogen temperature (77 K) [49].

\subsection{Electrochemical characterizations}


Before the electrochemical measurements, the glassware, polytetrafluoroethylene (PTFE)-based materials, volumetric flasks, tips and electrodes were cleaned in $50 \% \mathrm{v} / \mathrm{v}$ solution of $\mathrm{H}_{2} \mathrm{SO}_{4}$ (Merck, Suprapur 96 wt. \%) / $\mathrm{H}_{2} \mathrm{O}_{2}$ (Carl Roth, 30\% v/v), rinsed in ultrapure water (MQ grade, $18.2 \mathrm{M} \Omega \mathrm{cm}, 1-3 \mathrm{ppb}$ TOC) and hot ultrapure water. The glassy carbon tips (working electrode substrates) were polished on diamond polishing paste (Presi, 3 and $1 \mu \mathrm{m}$ ). All fresh Ar- and $\mathrm{O}_{2}$-saturated electrolytes were prepared from $\mathrm{NaOH}$ (Alfa Aesar, 50\% w/w aqueous solution) and ultrapure water to obtain a concentration of $0.1 \mathrm{M}$; similarly, $\mathrm{NaBH}_{4}$ fresh "mother solution" was prepared from previous $0.1 \mathrm{M} \mathrm{NaOH}$ solution and $\mathrm{NaBH}_{4}$ powder (Merck, $\geq 98.0 \%$ ) to obtain a concentration total of $0.5 \mathrm{M}$.

All electrochemical measurements were performed using a three-electrode PTFEelectrochemical cell with temperature control at $25^{\circ} \mathrm{C}$. The reference electrode was a commercial reversible hydrogen electrode (RHE, Gaskatel $\mathrm{GmbH}$ ) connected to the cell by a Luggin capillary and the counter electrode was a carbon sheet. The working electrode, a homemade glassy carbon cylinder (glassy carbon Sigradur $^{\circledR}$ from Hochtemperatur-Werkstoffe $\mathrm{GmbH}$ ) inserted in a PTFE cylinder, was connected to a commercial rotator (Origalys ${ }^{\circledR}$ ). To investigate the electrocatalyst materials, a catalytic layer was made onto the glassy carbon disc substrate $\left(0.196 \mathrm{~cm}^{2}\right)$ by dropping $20 \mu \mathrm{L}$ of each prepared ink to obtain a total catalyst loading of $0.8 \mathrm{mg}_{\text {powder }} \mathrm{cm}^{-2}$. The catalyst inks were prepared by dispersing $10 \mathrm{mg}$ of catalytic powder, $50 \mu \mathrm{L}$ of $5 \mathrm{wt}$. \% Nafion solution (Sigma-Aldrich), $854 \mu \mathrm{L}$ of isopropanol (Carl Roth) and $372 \mu \mathrm{L}$ of ultrapure water, followed by ultrasonic homogenization [51]. Then, the electrochemical cell was coupled to an Autolab PGSTAT12 potentiostat to perform RDE (rotating disk electrode) measurements. 
An initial reproducible surface state was obtained by applying 50 cyclic voltammograms (CVs) between 0.0 and $1.0 \mathrm{~V}$ vs. RHE at $100 \mathrm{mV} \mathrm{s}^{-1}$ in Ar-purged $0.1 \mathrm{M}$ $\mathrm{NaOH}$. Next, the CVs of the catalytic layers were recorded in the same conditions at 10 and $5 \mathrm{mV} \mathrm{s}^{-1}$, followed by polarization curves at $5 \mathrm{mV} \mathrm{s}^{-1}$ in $\mathrm{Ar}$ - and $\mathrm{O}_{2}$-saturated $0.1 \mathrm{M}$ $\mathrm{NaOH}$ electrolyte at $400 \mathrm{rpm}$. All polarization curves were subtracted by capacitive currents obtained $\left(\mathrm{CVs}\right.$ at $\left.5 \mathrm{mV} \mathrm{s}^{-1}\right)$ in Ar-purged electrolyte. This same procedure was repeated after each $\mathrm{NaBH}_{4}$ addition into the electrolyte $\left(\mathrm{NaBH}_{4}\right.$ concentration of 0,10 , 20, 40 and $60 \mathrm{mM}$ ). All measurements were corrected from ohmic drop.

Mass activity $\left(j_{\mathrm{MA}}=\frac{j_{\mathrm{k}}}{m}\right.$ at $0.85 \mathrm{~V} v s . \mathrm{RHE}$, where $m$ is the catalyst mass onto the glassy carbon electrode) was calculated from the kinetic current density for ORR $\left(j_{\mathrm{k}}\right)$ obatained by using the Koutecky Levich equation:

$$
j_{k}=-\frac{\left(j_{\mathrm{L}} \cdot j\right)}{\left(j_{\mathrm{L}}-j\right)}
$$

where $j_{\mathrm{L}}$ is the $\mathrm{O}_{2}$-diffusion limited current density at $0.2 \mathrm{~V} v s$. RHE and $j$ is the Faradaic current corrected as described above.

\section{Results and discussion}

\subsection{Physicochemical properties}

Detailed physicochemical characterizations of the catalysts have been previously published by Zitolo et al. [48,53], Choi et al. [50] and Kumar et al. [51]. High-resolution transmission electron microscopy and ${ }^{57} \mathrm{Fe}$ Mössbauer spectroscopy showed that the catalysts with 0.5 wt. \% metal content before pyrolysis (ca $1.5 \mathrm{wt} \%$ metal content after pyrolysis, due to the mass loss of ca $66 \%$ experienced by the sacrificial metal-organic framework ZIF-8 during pyrolysis) feature only atomically-dispersed metal atoms coordinated by nitrogen atoms and embedded into a carbon matrix $\left(\mathrm{FeN}_{\mathrm{x}}\right.$ sites). In contrast, the catalysts prepared with $5.0 \mathrm{wt}$. \% metal content before pyrolysis (ca $15 \mathrm{wt} \%$ 
metal after pyrolysis) resulted in either metallic (Co) or metal carbide $\left(\mathrm{Fe}_{3} \mathrm{C}\right)$ nanoparticles surrounded by a carbon-nitrogen shell. No atomically-dispersed metal atoms coordinated by nitrogen atoms[f1] were detected from the spectroscopic characterization of these samples. The Mössbauer or EXAFS spectroscopic detection limit for $\mathrm{FeN}_{\mathrm{x}}$ sites is $\mathrm{ca} .5 \%$ relative to the total amount of $\mathrm{Fe}$; so the absence of detection of $\mathrm{FeN}_{\mathrm{x}}$ sites monitored by these techniques for the 5.0 wt. \%-loaded $\mathrm{Fe}-\mathrm{N}-\mathrm{C}$ sample (ca $15 \mathrm{wt} \% \mathrm{Fe}$ total content $[\mathrm{f} 2])$ means that, at maximum, $0.75 \mathrm{wt} . \%$ Fe might be present as $\mathrm{FeN}_{\mathrm{x}}$ sites in this catalyst. In comparison, the 0.5 wt. $\%$-loaded $\mathrm{Fe}-\mathrm{N}-\mathrm{C}$ sample $(1.5 \mathrm{wt} \%$ Fe bulk content) only contains $\mathrm{FeN}_{\mathrm{x}}$ sites, and this implies that the absolute number of FeNx sites in the latter is at least double that in the 5.0 wt. \%-loaded Fe-N-C sample. Raman spectroscopy and X-ray diffraction provided evidences that the content of carbon nanocrystallites (i.e. more graphitic carbon phase, with lower amount of surface defects and oxygen functional groups) increases with the increase of metal content. Because ramp pyrolysis results in slow but continuous escape of the volatile products from ZIF-8 and phenanthroline decomposition, $c a$. twice higher Brunauer-Emmett-Teller (BET) surface area was observed for the ramp pyrolyzed Fe catalyst with 0.5 wt. \% Fe content compared to the flash pyrolyzed one [49]. However, this change mostly results in higher microporous surface area but little affects the meso-and macroporous surface areas [49]. In what follows, we refer to the catalysts as $\mathrm{M}_{\mathrm{x}}$ mode, where $\mathrm{M}$ is $\mathrm{Fe}$ or $\mathrm{Co}, x$ is the wt. $\%$ metal in the powder composed of mixed precursors before pyrolysis, either 0.5 or 5.0 and "mode" is the pyrolysis mode (either ramp or flash pyrolysis, RP and FP, respectively).

\subsection{Electrochemical properties}

In agreement with our former findings [54], it is found that: (i) all the electrocatalyst materials present very interesting oxygen reduction reaction activity in 
alkaline electrolytes and (ii) $\mathrm{Fe}-\mathrm{N}-\mathrm{C}$ electrocatalysts perform better than $\mathrm{Co}-\mathrm{N}-\mathrm{C}$ ones, independently to their structure and BET surface area. To probe their tolerance to sodium borohydride, the electrocatalysts were tested subsequently in $\mathrm{NaBH}_{4}$-free and $\mathrm{NaBH}_{4}$ containing Ar-saturated electrolytes. Fig. 1Fig. 1 shows the cyclic voltammograms obtained at $10 \mathrm{mV} \mathrm{s}^{-1}$ for all synthesized catalysts in $0.1 \mathrm{M} \mathrm{NaOH}$ electrolytes with different contents of $\mathrm{NaBH}_{4}$, in the absence of $\mathrm{O}_{2}$. Results reveal that none of the tested electrocatalysts are totally insensitive to the presence of $\mathrm{BH}_{4}{ }^{-}$anions in the electrolyte: all of them show non-negligible oxidation current in the "high-potential range", the magnitude of which increases with the $\mathrm{NaBH}_{4}$ concentration, signing they present some activity towards the electrooxidation of the $\mathrm{BH}_{4}^{-}$anion. However, clear differences can be seen when results for Fe-N-C and Co-N-C electrocatalysts are compared.

Focusing firstly on the Fe-containing materials (Fig. 1a), one notices that the 5.0 wt. \%-loaded Fe-N-C sample is much more sensitive to the presence of $\mathrm{NaBH}_{4}$ than its 0.5 wt. \% counterparts (the oxidation current monitored is ca. 10-times larger in the former than in the latter cases). These results are ascribed to the presence of $\mathrm{Fe}_{3} \mathrm{C}$ nanoparticles in the $\mathrm{Fe}_{5.0} \mathrm{RP}$ catalyst (which may contain no $\mathrm{FeN}_{\mathrm{x}}$ sites at all, and in the most favorable hypothesis for minor fraction of co-existing $\mathrm{FeN}_{\mathrm{x}}$ sites, does not contain more $\mathrm{FeN}_{\mathrm{x}}$ sites than the $\mathrm{Fe}_{0.5} \mathrm{RP}$ catalyst- see section 3.1), whereas the two other samples $\left(\mathrm{Fe}_{0.5} \mathrm{FP}\right.$ and $\left.\mathrm{Fe}_{0.5} \mathrm{RP}\right)$ exclusively contain atomically-dispersed iron coordinated by nitrogen ligands $\left(\mathrm{FeN}_{\mathrm{x}}\right.$ sites). It is believed that the lower reactivity of the $\mathrm{Fe}_{0.5}$-catalysts are related to the absence (or limited amounts) of neighbor sites required for the $\mathrm{BH}_{4}{ }^{-}$ anions adsorption and its subsequent oxidation. Comparing the $\mathrm{Fe}-\mathrm{N}-\mathrm{C}$ electrocatalysts prepared by the ramp pyrolysis (RP) or the flash pyrolysis (FP), results do not enable to differentiate the samples: $\mathrm{Fe}_{0.5} \mathrm{RP}$ and $\mathrm{Fe}_{0.5} \mathrm{FP}$ present similar reactivity in the presence 
of $\mathrm{NaBH}_{4}$ and are leading to very moderate BOR current (both contain atomicallydispersed iron).

Co-containing samples are, at given metal fraction, far more reactive for the BOR than their Fe-containing counterparts. $\mathrm{Co}_{0.5} \mathrm{RP}$, although presenting atomically-dispersed Co coordinated by N-ligands, leads to significant BOR currents particularly for $\mathrm{NaBH}_{4}$ concentration higher than $20 \mathrm{mM}$, and the situation is even worse for the Co5.0RP sample, that is constituted of Co nanoparticles (Fig. 1b, see inserted image to better visualization). In this last case, the electrode process must involve significant $\mathrm{H}_{2}$ release by $\mathrm{BH}_{4}^{-}$ hydrolysis, as evidenced by the instability of the catalyst thin-film, which prevented measurements for $\mathrm{NaBH}_{4}$ concentrations above $20 \mathrm{mM}$. These results illustrate the high ability of Co-N-C electrocatalysts to promote reactions with $\mathrm{NaBH}_{4}$. This property is not surprising for the $\mathrm{Co}_{5.0} \mathrm{RP}$ sample, owing to the already-reported activity of Co electrocatalysts for the $\mathrm{BOR}[55,56]$ or for the hydrolysis of $\mathrm{BH}_{4}{ }^{-}$followed by hydrogen release and subsequent oxidation [57-59]. The present results show that atomicallydispersed Co is also a good BOR electrocatalyst (Demirci et al. reported the activity of $\mathrm{Co}^{\mathrm{x}+}(x=2,3)$ cations for $\mathrm{BH}_{4}^{-}$hydrolysis [60], but not for the BOR). 

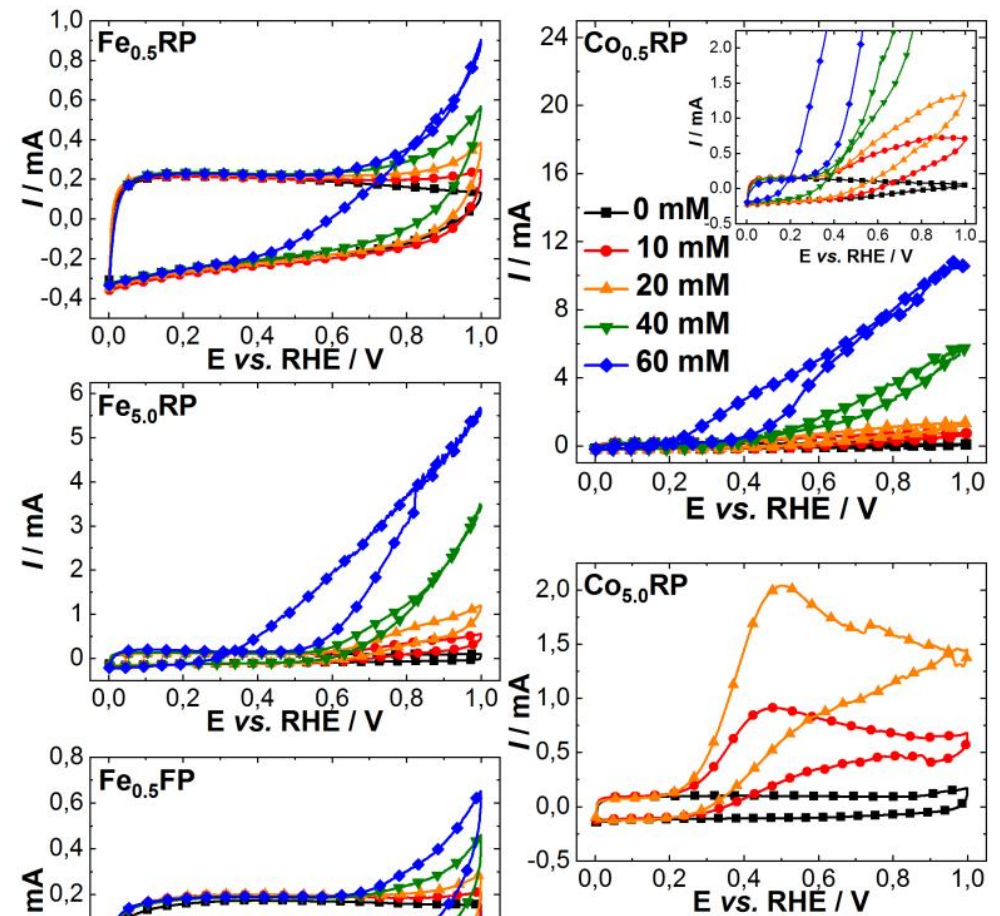

(b)

Fig. 1 Cyclic voltamperograms measured on a Fe-N-C and b Co-N-C electrocatalysts in Ar-purged $0.1 \mathrm{M} \mathrm{NaOH}$ supporting electrolyte containing increasing concentrations of $\mathrm{NaBH}_{4}: 0,10,20,40$ and $60 \mathrm{mM}$. All the tests were performed at $25^{\circ} \mathrm{C}$ and $10 \mathrm{mV} \mathrm{s}^{-1}$; the M-N-C electrocatalyst loading on the RDE tip was in all measurements $0.8 \mathrm{mg}_{\text {powder }}$ $\mathrm{cm}^{-2}$. For the Co5.0RP sample, the active layer was destroyed for $\left[\mathrm{NaBH}_{4}\right]>20 \mathrm{mM}$.

The electrocatalysts were then tested for the ORR in absence and presence of $\mathrm{NaBH}_{4}$ at several concentrations in $\mathrm{O}_{2}$-saturated electrolytes (Fig. 2). In all cases, the "direct" measurement of the ORR in the presence of $\mathrm{NaBH}_{4}$ (represented by the curves (3), in symbols) are compared to the "reconstructed" ones, for which the ORR currents in absence of $\mathrm{NaBH}_{4}$ are added to the currents of $\mathrm{BH}_{4}{ }^{-}$oxidation in Ar-saturated supporting electrolyte (represented by the curves $(4+2)$, in dotted lines). For the majority of 
considered electrocatalyst considered, the "direct" and "reconstructed" curves of ORR in the presence of $\mathrm{NaBH}_{4}$ are near-superposed; this means that the processes at stake on these class of materials is indeed the sum of the ORR and of the BOR (or of $\mathrm{BH}_{4}^{-}$ hydrolysis followed by the oxidation of the produced $\mathrm{H}_{2}$ ), meaning that the processes are independent from each other.

Furthermore, one clearly sees that not all the electrocatalysts have the same reactivity for the ORR in the presence of $\mathrm{NaBH}_{4}$, in agreement to the conclusions obtained from Fig. 1. Firstly, Fe-N-C electrocatalysts presenting only atomically-dispersed iron $\left(\mathrm{Fe}_{0.5} \mathrm{RP}\right.$ and $\left.\mathrm{Fe}_{0.5} \mathrm{FP}\right)$ are somewhat tolerant to $\mathrm{NaBH}_{4}$ : the ORR activity in presence of $10 \mathrm{mM} \mathrm{NaBH}_{4}$ is hardly changed compared to its value in absence of $\mathrm{NaBH}_{4}$. However, increasing the $\mathrm{NaBH}_{4}$ concentration progressively from 10 to $60 \mathrm{mM}$ leads to an increase of BOR contribution to the total current, causing a slight negative shift of the apparent ORR onset potential (a sign of depreciated ORR kinetics and/or appearance of mixed electrode potentials, Fig. 2a). Surprisingly, increasing $\mathrm{NaBH}_{4}$ concentrations lead to practically unaffected absolute value of the ORR limiting currents (see curves (3), symbols), which one could associate to similar number of electrons involved in ORR electrocatalysis even in the presence of strong reducer. Another interesting aspect is the smaller "direct" ORR limiting currents compared to the sum of the ORR and the BOR (see curves $(4+2)$, dotted lines); it can be related to the reduction of oxygen by $\mathrm{BH}_{4}^{-}$ anions on the catalysts surface, which in fact reduces the local effective concentration of $\mathrm{O}_{2}$ in the "direct" measurements.

In contrast, when $\mathrm{Fe}_{3} \mathrm{C}$ nanoparticles are present $\left(\mathrm{Fe}_{5.0} \mathrm{RP}\right)$, the $\mathrm{BH}_{4}^{-}$tolerance is no longer maintained: the ORR activity of $\mathrm{Fe}_{5.0} \mathrm{RP}$ is severely affected by increasing amounts of $\mathrm{NaBH}_{4}$, and even at $10 \mathrm{mM} \mathrm{NaBH}_{4}$, the reaction onset potential is severely negatively-shifted (by more than $100 \mathrm{mV}$; the negative shift being > $400 \mathrm{mV}$ for $60 \mathrm{mM}$ 
$\mathrm{NaBH}_{4}$ ). Moreover, increasing $\mathrm{NaBH}_{4}$ concentration leads to decreased absolute values of ORR limiting currents, which indicates a lower number of electrons involved in the $\mathrm{O}_{2}$ electrocatalysis and/or a drastic reduction of $\mathrm{O}_{2}$ concentration in the catalyst surface (probably because of a reaction of $\mathrm{O}_{2}$ or ORR intermediates (i.e. $\mathrm{HO}_{2}{ }^{-}$) with $\mathrm{BH}_{4}{ }^{-}$or $\mathrm{H}_{2}$ [61]). Not surprisingly, Co-N-C samples, which showed non-negligible activity towards the BOR (Fig. 1), are not capable to maintain their good ORR activity in presence of $\mathrm{NaBH}_{4}$ in the electrolyte, even at low concentration (Fig. 2b). Of course, in presence of Co nanoparticles $\left(\mathrm{Co}_{5.0} \mathrm{RP}\right)$, the $\mathrm{NaBH}_{4}$ tolerance is even worse as compared to that of atomically-dispersed $\mathrm{Co}\left(\mathrm{Co}_{0.5} \mathrm{RP}\right)$.
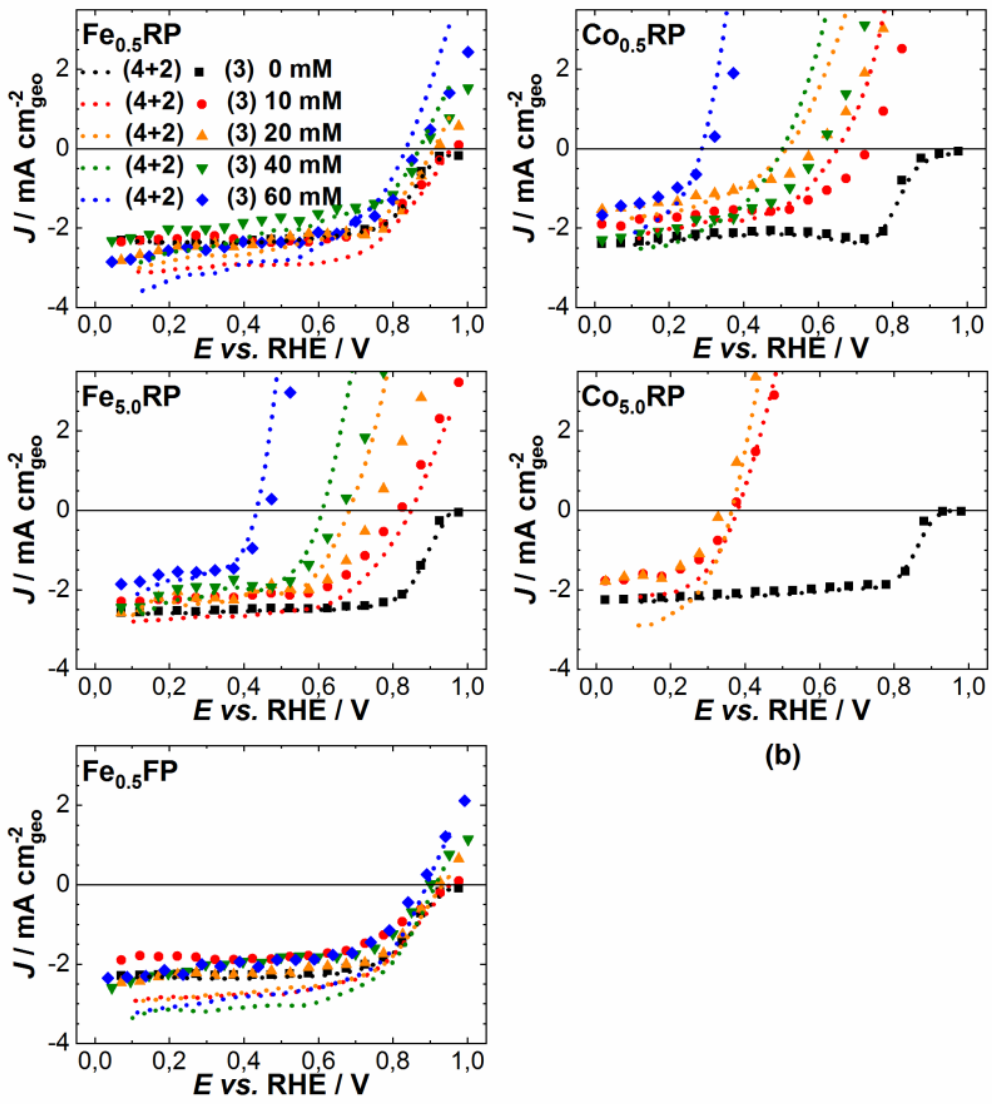

(b)

(a)

Fig. 2 Cyclic voltamperograms of oxygen reduction reaction measured on a Fe-N-C and b Co-N-C electrocatalysts in $\mathrm{O}_{2}$-purged $0.1 \mathrm{M} \mathrm{NaOH}$ supporting electrolyte containing increasing concentrations of $\mathrm{NaBH}_{4}: 0,10,20,40$ and $60 \mathrm{mM}$. All the tests were 
performed at $25^{\circ} \mathrm{C}, 400 \mathrm{rpm}$ and $5 \mathrm{mV} \mathrm{s}^{-1}$; the M-N-C electrocatalyst loading on the RDE tip was in all measurements $0.8 \mathrm{mg}_{\text {powder }} \mathrm{cm}^{-2}$. (symbols) “direct" experimental curves of ORR in the presence of NaBH4; (dotted lines) sum of current of ORR in absence of $\mathrm{NaBH} 4$ with those for the BOR (similar as Fig. 1).

The ORR onset potential ( $\left.E_{\text {onset }}\right)$, half-wave potential $\left(E_{\text {half-wave }}\right)$ and mass activity (jMA at $0.85 \mathrm{~V} v s . \mathrm{RHE}$ ) of all the electrocatalysts were determined in the "direct" ORR experiments as a function of the $\mathrm{NaBH}_{4}$ concentration in the electrolyte, as shown Fig. 3. The drastic reduction of the onset and half-wave potentials observed in Fig. 3a and Fig. 3 b confirm that for $\mathrm{Fe}_{5.0} \mathrm{RP}$ or $\mathrm{Co}-\mathrm{N}-\mathrm{C}$ samples $\left(\mathrm{Co}_{0.5} \mathrm{RP}\right.$ and the $\left.\mathrm{Co}_{5.0} \mathrm{RP}\right)$, the tolerance to $\mathrm{NaBH}_{4}$ is insufficient: these electrocatalysts present highly-degraded ORR performances both in the kinetically-controlled and in the mixed kinetic-diffusion control regions as soon as some $\mathrm{NaBH}_{4}$ is present in the electrolyte.

In this way, the results evidence that only the atomically-dispersed $\mathrm{Fe}-\mathrm{N}-\mathrm{C}$ electrocatalysts present a sufficient tolerance to $\mathrm{BH}_{4}{ }^{-}$to be used as ORR electrocatalysts in a DBFC cathode, even though their ORR performances would start to non-negligibly decrease if the crossover of $\mathrm{NaBH}_{4}$ is significant and the $\mathrm{BH}_{4}^{-}$concentration exceeds a few $10 \mathrm{mM}$. This is further highlighted by results in Fig. 3c, which demonstrate that the intrinsic mass activity of the $\mathrm{Fe}_{0.5} \mathrm{RP}$ and $\mathrm{Fe}_{0.5} \mathrm{FP}$ electrocatalysts are not drastically affected by concentrations of $\mathrm{NaBH}_{4}$ in the $\mathrm{NaOH}$ supporting electrolyte, at least for $\mathrm{BH}_{4}{ }^{-}$ concentrations of the order of $10 \mathrm{mM}$. These results also show that the electrocatalyst prepared by ramp pyrolysis $\left(\mathrm{Fe}_{0.5} \mathrm{RP}\right)$ is a little more tolerant than the one prepared by flash pyrolysis $\left(\mathrm{Fe}_{0.5} \mathrm{FP}\right)$. This behavior may be related to the above-mentioned difference in BET surface area, which facilitates the access of oxygen molecules. Note however that 
this effect progressively vanishes by increasing $\left[\mathrm{BH}_{4}{ }^{-}\right]$concentrations in solution to values that far exceed the $\mathrm{O}_{2}$ solubility $(1-2 \mathrm{mM})$.
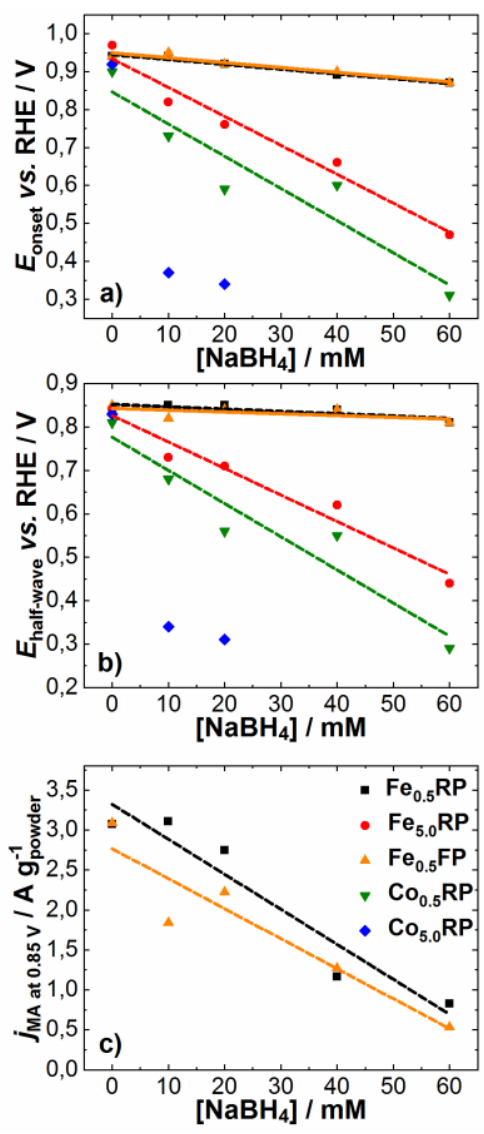

Fig. 3 Determination of representative oxygen reduction reaction kinetic parameters for the $\mathrm{Fe}-\mathrm{N}-\mathrm{C}$ and $\mathrm{Co}-\mathrm{N}-\mathrm{C}$ electrocatalysts measured in $\mathrm{O}_{2}$-purged $0.1 \mathrm{M} \mathrm{NaOH}$ supporting electrolyte containing increasing concentrations of $\mathrm{NaBH}_{4}: 0,10,20,40$ and $60 \mathrm{mM}$. All the tests were performed at $25^{\circ} \mathrm{C}, 400 \mathrm{rpm}$ and $5 \mathrm{mV} \mathrm{s}{ }^{-1}$; the M-N-C electrocatalyst loading on the RDE tip was in all measurements $0.8 \mathrm{mg}_{\text {powder }} \mathrm{cm}^{-2}$. a ORR onset potential and $\mathbf{b}$ ORR half-wave potential, measured for all the M-N-C electrocatalysts; c ORR mass activities measured at $0.85 \mathrm{~V} v s$. RHE (corrected from mass-transfer limitation) for the atomically-dispersed Fe-N-C electrocatalysts (the measurement made no sense for the other electrocatalysts).

\section{Conclusions}


The present study shows that by tuning the nature of the metal center, its structure (atomic dispersion vs. nanoparticles) and the BET surface area of the carbonaceous structure, the tolerance of the ORR to $\mathrm{NaBH}_{4}$ can be enhanced in the potential range of a direct borohydride fuel cell cathode. Evidences of a positive structural effect on the tolerance to $\mathrm{BH}_{4}{ }^{-}$competition were obtained for catalysts containing atomically-dispersed $\mathrm{Fe}$ and Co sites, the latter being magnified for Fe-containing electrocatalysts because of combined poor activity towards the BOR and high activity towards the ORR. A small but non-negligible effect of the microporous surface area was observed; however, it is believed that it relates to higher density of active sites in catalysts after ramp- compared to flash-pyrolysis. These findings thus open the door to enhanced electrocatalysts for the DBFC both at atomic and macroscopic levels.

\section{Acknowledgements}

This study was financially supported by the French National Research Agency through the CAT2CAT and ANIMA projects. R.S. gratefully acknowledges the Coordenação de Aperfeiçoamento de Pessoal de Nível Superior (CAPES), Brazil (process number: 1614344), CAPES/COFECUB program (process numbers: 88887-187755/2018-00 and Ph-C 914/18) for funding his research stay at LEPMI and the São Paulo State Research Foundation (FAPESP - process number: 2013/16930-7) for financial supports. Some materials' analyses have been performed within "CEMAM", the Centre of Excellence of Multifunctional Architectured Materials ( ${ }^{\circ}$ ANR-10-LABX-44-01).

\section{References}

1. D. Linden and T. B. Reddy, Handbook of Batteries, Fourth ed. (McGraw-Hill, New York, 2011). 
2. W. Vielstich, A. Lamm, and H. A. Gasteiger, Handbook of Fuel Cells: Fundamentals, Technology and Applications (Wiley, Chichester, 2003).

3. S. Wasmus and A. Küver, J. Electroanal. Chem. 461, 14 (1999).

4. H. A. Gasteiger, W. Vielstich, and H. Yokokawa, Hanbook of Fuel Cells (Wiley, Chichester, 2009).

5. J. S. Spendelow and A. Wieckowski, Phys. Chem. Chem. Phys. 9, 2654 (2007).

6. J. H. Wee, J. Power Sources 161, 1 (2006).

7. U. B. Demirci, J. Power Sources 169, 239 (2007).

8. S. C. Amendola, P. Onnerud, M. T. Kelly, P. J. Petillo, S. L. Sharp-Goldman, and M. Binder, J. Power Sources 84, 130 (1999).

9. C. Kim, K. J. Kim, and M. Y. Ha, J. Power Sources 180, 114 (2008).

10. B. H. Liu and Z. P. Li, J. Power Sources 187, 291 (2009).

11. J. Ma, N. A. Choudhury, and Y. Sahai, Renew. Sustain. Energy Rev. 14, 183 (2010).

12. G. Rostamikia and M. J. Janik, Energy Environ. Sci. 3, 1262 (2010).

13. M. Chatenet, M. B. Molina-Concha, and J. P. Diard, Electrochim. Acta 54, 1687 (2009).

14. D. A. Finkelstein, N. Da Mota, J. L. Cohen, and H. D. Abruña, J. Phys. Chem. C 113, 19700 (2009).

15. B. Molina Concha, M. Chatenet, E. A. Ticianelli, and F. H. B. Lima, J. Phys. Chem. C 115, 12439 (2011). 
16. P. Y. Olu, A. Bonnefont, M. Rouhet, S. Bozdech, N. Job, M. Chatenet, and E. Savinova, Electrochim. Acta 179, 637 (2015).

17. M. C. S. Escaño, R. L. Arevalo, E. Gyenge, and H. Kasai, J. Phys. Condens. Matter 26, (2014).

18. P.-Y. Olu, A. Bonnefont, and M. Chatenet, in Encycl. Interfacial Chem. - Surf. Sci. Electrochem., edited by K. Wandelt (Waltham, MA, USA, 2017), p. 15.

19. P.-Y. Olu, A. Zadick, N. Job, and M. Chatenet, in Electrocatal. Low Temp. Fuel Cells Fundam. Recent Trends, edited by T. Maiyalagan and S. V. Saji (Wiley, 2017), pp. 317346.

20. I. Merino-Jiménez, C. Ponce De León, A. A. Shah, and F. C. Walsh, J. Power Sources 219, 339 (2012).

21. K. S. Freitas, B. M. Concha, E. A. Ticianelli, and M. Chatenet, Catal. Today 170, 110 (2011).

22. S. Suda, in Handb. Fuel Cells, edited by W. Vielstich, H. A. Gasteiger, and A. Lamm (Wiley, Chichester, 2003), pp. 115-120.

23. C. Ponce De León and F. C. Walsh, Direct and Indirect Borohydride Fuel Cells, Reference Module in Chemistry, Molecular Sciences and Chemical Engineering (Elsevier, 2015).

24. Z. Wang, J. Parrondo, C. He, S. Sankarasubramanian, and V. Ramani, Nat. Energy 4, 281 (2019).

25. M. Chatenet, Nat. Energy 4, 261 (2019). 
26. S. Ould-Amara, J. Dillet, S. Didierjean, M. Chatenet, and G. Maranzana, J. Power Sources 439, 227099 (2019).

27. K. N. Mochalov, V. S. Khain, and G. G. Gilmanshin, Dokl. Akad. Nauk SSSR 162, $613(1965)$.

28. M. M. Kreevoy and R. W. Jacobson, Vent. Alembic 15, 2 (1979).

29. D. Sebastián, A. Serov, I. Matanovic, K. Artyushkova, P. Atanassov, A. S. Aricò, and V. Baglio, Nano Energy 34, 195 (2017).

30. K. B. Ma, D. H. Kwak, S. B. Han, H. S. Park, D. H. Kim, J. E. Won, S. H. Kwon, M. C. Kim, S. H. Moon, and K. W. Park, ACS Sustain. Chem. Eng. 6, 7609 (2018).

31. L. Osmieri, R. Escudero-Cid, A. H. A. Monteverde Videla, P. Ocón, and S. Specchia, Renew. Energy 115, 226 (2018).

32. A. C. Garcia, J. J. Linares, M. Chatenet, and E. A. Ticianelli, Electrocatalysis 5, 41 (2014).

33. E. A. Ticianelli and F. H. B. Lima, in Direct Alcohol Fuel Cells Mater. Performance, Durab. Appl., edited by H. R. Corti and E. R. Gonzalez (Springer, 2014), pp. 99-119.

34. X. Wei, X. Yang, S. Li, Y. Chen, and Y. Liu, Electrochim. Acta 56, 7523 (2011).

35. M. Chatenet, F. Micoud, I. Roche, E. Chainet, and J. Vondrák, Electrochim. Acta 51, $5452(2006)$.

36. A. C. Garcia, F. H. B. Lima, E. A. Ticianelli, and M. Chatenet, J. Power Sources 222 , 305 (2013).

37. I. Roche, E. Chaînet, M. Chatenet, and J. Vondrák, J. Appl. Electrochem. 38, 1195 
(2008).

38. H. Cheng and K. Scott, J. Electroanal. Chem. 596, 117 (2006).

39. M. Chatenet, F. Micoud, I. Roche, and E. Chainet, Electrochim. Acta 51, 5459 (2006).

40. M. H. Atwan, D. O. Northwood, and E. L. Gyenge, Int. J. Hydrogen Energy 32, 3116 (2007).

41. A. V. Narendra Kumar, S. Harish, and J. Joseph, Bull. Mater. Sci. 37, 635 (2014).

42. D. M. F. Santos, B. Šljukić, L. Amaral, D. Macciò, A. Saccone, and C. A. C. Sequeira, J. Electrochem. Soc. 161, 594 (2014).

43. A. G. Oshchepkov, G. Braesch, S. Ould-Amara, G. Rostamikia, G. Maranzana, A. Bonnefont, V. Papaefthimiou, M. J. Janik, M. Chatenet, and E. R. Savinova, ACS Catal. 9, $8520(2019)$

44. A. Serov, A. Aziznia, P. H. Benhangi, K. Artyushkova, P. Atanassov, and E. Gyenge, J. Mater. Chem. A 1, 14384 (2013).

45. M. Lefèvre, E. Proietti, F. Jaouen, and J.-P. Dodelet, Science (80-. ). 324, 71 (2009).

46. A. Serov, K. Artyushkova, E. Niangar, C. Wang, N. Dale, F. Jaouen, M. T. Sougrati, Q. Jia, S. Mukerjee, and P. Atanassov, Nano Energy 16, 293 (2015).

47. F. Luo, C. H. Choi, M. J. M. Primbs, W. Ju, S. Li, N. D. Leonard, A. Thomas, F. Jaouen, and P. Strasser, ACS Catal. 9, 4841 (2019).

48. N. Ranjbar-Sahraie, A. Zitolo, E. Fonda, T. Mineva, S. Mukerjee, S. Stamatin, S. M. Lyth, J. Li, F. Jaouen, P. Krtil, Q. Jia, and G. F. Harrington, Nat. Commun. 8, 1 (2017). 
49. V. Armel, J. Hannauer, and F. Jaouen, Catalysts 5, 1333 (2015).

50. C. H. Choi, H. K. Lim, M. W. Chung, G. Chon, N. Ranjbar Sahraie, A. Altin, M. T. Sougrati, L. Stievano, H. S. Oh, E. S. Park, F. Luo, P. Strasser, G. Dražić, K. J. J. Mayrhofer, H. Kim, and F. Jaouen, Energy Environ. Sci. 11, 3176 (2018).

51. K. Kumar, P. Gairola, N. Ranjbar-Sahraie, F. Maillard, L. Dubau, M. Mermoux, A. Zitolo, M. Lions, and F. Jaouen, ACS Catal. 8, 11264 (2018).

52. V. Goellner, V. Armel, A. Zitolo, E. Fonda, and F. Jaouen, J. Electrochem. Soc. 162, H403 (2015).

53. A. Zitolo, V. Goellner, V. Armel, M. T. Sougrati, T. Mineva, L. Stievano, E. Fonda, and F. Jaouen, Nat. Mater. 14, 937 (2015).

54. R. Sgarbi, K. Kumar, F. Jaouen, A. Zitolo, E. A. Ticianelli, and F. Maillard, J. Solid State Electrochem. 1 (2019).

55. J. Ma, X. Gao, D. Wang, T. Xue, and S. Yang, J. Alloys Compd. 724, 474 (2017).

56. A. Tiwari, V. Singh, and T. C. Nagaiah, ACS Appl. Mater. Interfaces 11, 21465 (2019).

57. A. Garron, D. Świerczyński, S. Bennici, and A. Auroux, Int. J. Hydrogen Energy 34, 1185 (2009).

58. J. Choi and J. Chung, J. Energy Eng. 142, 2 (2016).

59. R. Edla, S. Gupta, N. Patel, N. Bazzanella, R. Fernandes, D. C. Kothari, and A. Miotello, Appl. Catal. A Gen. 515, 1 (2016).

60. J. Hannauer, U. B. Demirci, C. Geantet, J. M. Herrmann, and P. Miele, Phys. Chem. 
Chem. Phys. 13, 3809 (2011).

61. A. C. Garcia, F. H. B. Lima, E. A. Ticianelli, and M. Chatenet, J. Power Sources 222, 305 (2013). 